the Esthwaite basin. The drop in tree pollen, rise in grass pollen and occurrence of Plantago lanceolata suggest that this horizon may represent the beginnings of cultivation in the area.

A useful warning to modern collectors and commentators was implied in the exhibit by Mrs. H. N. Clokie (Department of Botany, University of Oxford) of selected sheets from the Du Bois (1690-1723) and Sherardian (1700-26) herbaria. These showed the confusion and loss of information which can result from illegible labels, or from mounting plants which could not be certainly associated with their labels. The Library of the British Museum (Natural History) displayed a magnificent series of unpublished drawings prepared for Church's "Types of Floral Mechanism" and unpublished text. The view was freely expressed that the publication of these fine additional drawings would be a valuable addition to the book already available.

A full account of the exhibits will appear in due course in the Proceedings of the Society. The meeting was attended by about two hundred and eighty members and guests.

J. E. Lousley

${ }^{1}$ Lousley, J. E., Nature, 173, 113 (1954).

${ }^{2}$ Lousley, J. E., Nature, 171, 335 (1953).

'Hultén, E., Nytt Mag. Bot., 3, 67 (1954).

- Davies, E., Watsonia, 3, 71 (1953).

${ }^{5}$ Heslop-Harrison, J., Watsonia, 3, 7 (1953).

- Wycherley, P. R., Watsonia, 3, 41 (1953).

? Green, P. S., Watsonia, 3, 122 (1954).

- Hambler, D. J., Nature, 174, 838 (1954).

- Walters, S. M., Nature, 173, 1079 (1954).

\section{HYDRAULIC TRANSPORT OF COAL}

$\mathrm{T}$

RANSPORT of coal from the mines to the user represents an appreciable proportion of the energy in the fuel. Normally this is done by rail or sea transport; but transportation through pipes as a suspension in water is another possibility. The advantages of hydraulic transport over short distances within the workings of the colliery are apparent-either underground or on the surface, or even as an alternative to normal cage winding. There is, however, the possibility that hydraulic transport of coal could be operated over much longer distances; this has already been accomplished up to five miles, and a hundred-mile pipe-line is planned in the Pittsburgh area. These advantages and many others were described by Dr. Idris Jones, directorgeneral of research, National Coal Board, in an introductory address to a colloquium on "The Hydraulic Transport of Coal" held by the National Coal Board in London during November 5-6, 1952 (pp. vi +75 . London: National Coal Board, 1954), which was opened by Sir Charles Ellis.

Although there is in existence much experimental data on the transport of solid material by water streams in open channels and pipes, the numerous factors involved have hindered the formulation of any theory which will give a full understanding of the transport process in pipes. The purpose of the colloquium was to assemble and compare such results as are available and to discuss tentative theories. The first four papers dealt mainly with fundamental theory and the development of dimensionless groups characterizing the flow of suspensions through pipes, with lump sizes up to 4 in. Some of the authors admitted that the present theory is inadequate, and it is evident that this is only the beginning of research on this subject. The second group of four papers described the development of coal feeders and experimental installations in France and at Markham Colliery.

The discussion on the papers is included in the publication, and the proceedings form a useful basis for further study of a subject which is becoming of increasing practical importance. H. HEYwOOD

\section{RECENT WORK IN MAYAN ARCHAOLOGY}

$\mathrm{O}$ VER a long period of years, the Carnegie In. stitution, through its Archæological Department, has produced a most valuable series of publications, most of which deal with the Maya area. The shorter studies in this series have appeared in volumes of Contributions, of which that under review is a useful example*.

No. 52, by Howel Williams, deals with some human and animal footprints first discovered seventy years ago on the outskirts of Managua, Nicaragua, which aroused a great deal of interest when they were found, owing to their supposedly great age. This was based on the considerable depth of four metres at which they were found, and was estimated at 50,000 years or more. Further examples were found at the same horizon in 1941, so it has been possible to study the question afresh. Williams shows that the deposits in and under which they occur are pumices and midflows associated with vulcanicity, which must have been accumulated at a great rate, so that their age has been grossly exaggerated. The prints are abundant, and may well have been made by people fleeing from a rain of ash from the volcano Masaya. On the scanty evidence of a sheard of Usulutan ware found on the site at a considerably higher level, it is concluded that the footprints are between 3,000 and 5,000 years old. The author holds out little hope of obtaining material for radiocarbon dating, so it is unlikely that this estimate can be improved on.

The second paper, No. 53, by A. V. Kidder and E. M. Shook, describes the partial excavation of a complex temple mound containing at least two important burials at the Maya site of Kaminaljuyú, near Guatemala City. The authors, with J. D. Jennings, have already published an important work on Kaminaljuyú; but it is a very large site and a great deal remains to be done. This was largely a rescue dig, necessitated by the destruction of part of the mound by brick-making activities. The mound proved to belong to the Miraflores phase of the PreClassic or Middle Culture Period, dating in all probability from the first part of the first millennium B.C. ; the authors had suspected that this might be so, but had been loth, in the absence of positive proof, to ascribe so large and complex a structure to this early period. The importance of the work lies mainly in the recognition of this fact, which may make it necessary to postulate the emergence of 'Classic' social structures, for example, a ruling class, in pre-Classic times, and perhaps to revise our chronological nomenclature accordingly.

Something is known of the archæological record of the Maya in Northern Yucatan from the Formative * Contributions to American Anthropology and History. Vol. 11, Nos. 52-56. (Publication 596.) Pp. vi +236. (Washington, D.C.: 7.50 dollars, cloth. 